\title{
Physical Activity During School Recess and Physical Education Among Deaf School Children ${ }^{1}$ ATIVIDADE Física DURANTE O RECREIO ESCOLAR E EDUCAÇÃo FÍSICA EM CRIANÇAS SURDAS
}

\author{
Paulina Yesica OCHOA MARTÍNEZ² \\ Javier Arturo HALL LÓPEZ ${ }^{3}$ \\ Ana Maria TEIXEIRA ${ }^{4}$
}

\begin{abstract}
The objective of this study was to determine comparatively the physical activity in Physical Education and school recess of hearing-impaired students in Primary Education. Fifty-eigth Physical Education classes and recess in Primary Education were evaluated in a representative way, in specialized educational institutions for people with hearing disabilities. Physical activity was determined using the system for observing fitness instruction time (SOFIT). Inferential statistics, using the Student's t-test, reported significant differences with more moderate to vigorous physical activity performed during recess than in Physical Education. The same pattern was identified in schoolchildren without diagnosed disabilities. It is recommended that teachers guide the content for the development of coordinating skills that favor the gross and fine motor conditions of this population, implementing didactic strategies that increase the amount of moderate to vigorous activity in Physical Education that is greater than that performed during recess.
\end{abstract}

KEYWORDS: Physical Education. Hearing impairment. School recess.

RESUMO: O objetivo deste estudo foi determinar comparativamente a atividade física na Educação Física e no recreio escolar de alunos com deficiência auditiva no Ensino Fundamental. Foram avaliadas 58 aulas de Educação Física e o recreio no Ensino Fundamental, de forma representativa, em instituiçóes de ensino especializadas para pessoas com deficiência auditiva. A atividade física foi determinada usando o sistema de observação do tempo de instrução de fitness (SOFIT). A estatística inferencial, usando o teste t de Student, relatou diferenças significativas com atividades físicas mais moderadas a vigorosas realizadas durante o recreio do que na Educação Física. O mesmo padrão foi identificado em alunos sem deficiência diagnosticada. Recomenda-se aos professores orientar o conteúdo para o desenvolvimento de coordenar capacidades que favoreçam as condiçóes motoras grossas e finas dessa população, implementando estratégias didáticas que aumentem a quantidade de atividade moderada a vigorosa na Educação Física que seja maior do que a realizada no recreio.

PALAVRAS-CHAVE: Educação Física. Deficiência auditiva. Recreio.

\footnotetext{
${ }^{1}$ https://doi.org/10.1590/1980-54702022v28e0112

${ }^{2} \mathrm{PhD}$ in teaching of physical activity and sport at the University of Huelva. Associate professor of the Faculty of Sports of the Autonomous University of Baja California, Mexico. Postdoctorate student in sport sciences at the Faculty of Sport Sciences and Physical Education, University of Coimbra, Portugal. Scholarship holder of the Ibero-American Postgraduate University Association (AUIP), in the International Academic Mobility Program among all the institutions associated with the AUIP call $2020-2021$. Mexicali/Baja California/Mexico. E-mail: pochoa@uabc.edu.mx. ORCID: https://orcid.org/0000-0001-8107-4906

${ }^{3} \mathrm{PhD}$ in teaching of physical activity and sport at the University of Huelva. Associate professor of the Faculty of Sports of the Autonomous University of Baja California, Mexico. Postdoctorate student in sport sciences at the Faculty of Sport Sciences and Physical Education, University of Coimbra, Portugal. Scholarship holder of the Ibero-American Postgraduate University Association (AUIP), in the International Academic Mobility Program among all the institutions associated with the AUIP call 2020-2021. Mexicali/Baja California/Mexico. E-mail: javierhall@uabc.edu.mx. ORCID: https://orcid.org/0000-0002-7808-0181

${ }^{4} \mathrm{PhD}$ in Haemathology by London Medical School, University College London. Associated Professor with aggregation and coordinator of the PhD course in Sport Sciences at the Faculty of Sport Sciences and Physical Education, University of Coimbra, Portugal. Coimbra/Coimbra/Portugal. E-mail: ateixeira@fcdef.uc.pt. ORCID: https://orcid.org/0000-0003-1498-949X
} 


\section{INTRODUTION}

Systematic reviews establish that physical activity performed by children with disabilities is less practiced than people without disabilities (Jung et al., 2018; Li et al., 2016). A meta-analysis identified that physically active students of school-age with hearing impairment have a better quality of life than students with a sedentary lifestyle (Kitterick et al., 2015). It has been reported that only $20 \%$ of boys, girls, and adolescents with hearing impairment comply with the recommended quantity by the World Health Organization (WHO, 2010), being 60 minutes daily of moderate to vigorous physical activity (Li et al., 2019). Research in basic education that has assessed the physical activity of students with hearing impairment reports sedentary behaviors during the school day (Sit et al., 2007; Sit et al., 2019), which is unfavorable for this section of the population, due to the etiological nature of hearing impairment; which partially or limits hearing in one or both ears (Franco \& Panhoca, 2008), which generates poor motor skills with low levels of coordinative physical capacities (Jafarnezhadgero et al., 2017; Rajendran \& Roy, 2011; Walicka-Cupryś et al., 2014). Based on intervention studies in Physical Education, the practice of physical activity for motor skill development in students with hearing impairment has been widely recommended (Ochoa-Martínez et al., 2018; Ochoa-Martínez et al., 2019).

Internationally, vigorous to moderate physical activity is considered part of the quality standards in Physical Education, for example, the National Association for Sport and Physical Education (NASPE) recommends Physical Education teachers promote the participation of moderate to vigorous physical activity in students for at least $50 \%$ of the total Physical Education class time (Baghurst et al., 2015). Regarding school recess, it has been identified as a time frame to promote the practice of physical activity (Baquet et al., 2018; Galbraith \& Normand, 2017). Ridgers et al. (2011), reports that during recess time, students can reach up to $40 \%$ of the recommended daily physical activity.

Studies establish multiple factors in the school day that promote the practice of physical activity in students, such as infrastructure, available space, the educational model utilized, and the content direction of teachers (Chen et al., 2018; Hollis et al., 2014). Within the Mexican context, research during Physical Education and recess has assessed moderate to vigorous physical activity in students of school-age without the impairment (Hall-López et al., 2017; Hall-López et al., 2018). In this sense, the WHO (2011) refers in the World Report on Disability that the number of people with disabilities is on the rise. These are considered a vulnerable population with fewer possibilities than their non-disabled counterparts of entering basic education, staying in it, and enrolling in successive school years. Regarding physical activity of people with disabilities, it is reported that only $33.8 \%$ of schoolchildren with disabilities perform any sports or physical activity apart from Physical Education (Jung et al., 2013), according to our knowledge, we have not identified any research within the Mexican context that evaluates physical activity in students with hearing impairment, the above is important as a basis for action by teachers working in the field of Physical Education around people with disabilities (Andrade \& Freitas, 2016) and have teaching-learning conditions with inclusive methods (Simóes et al., 2018) since the United Nations Educational, Scientific and Cultural Organization (UNESCO), manifests in its guide for policy makers in Physical Education to focus inclusive methodologies aimed at raising awareness about people with disabilities, pro- 
moting values during Physical Education class, and should also be regulated for promotion among students, parents, and members of the community (Mclennan \& Thompson, 2015). Therefore, this research aims to comparatively determine physical activity during Physical Education class, and recess of students with hearing impairment in primary school.

\section{Method}

\subsection{Participants}

The research was authorized and registered in the Office of Graduate Studies and Research of the Autonomous University of Baja California and was approved by the Faculty of Sports. The studies were performed using a comparative descriptive cross-sectional method (Thomas et al., 2015), and were conducted in two educational institutions in Mexicali Baja California, Mexico; that offer specialized education for people with hearing impairment according to the International Classification of Functioning, Disability and Health (ICF) established by the WHO (2013), which has as criteria people with a total or partial deficit of perception that is evaluated with the loss of audio of each ear. Exemption from participation was requested from administrators, teachers, and parents, and following the ethical principles of research involving human subjects of the declaration of Helsinki, taking into account the participation of children and young people (Rupali, 2005).

\subsection{INSTRUMENT}

The universe was made up of 140 Physical Education classes that took place during the school year, in the two educational institutions that provide care for students with hearing impairment, 58 Physical Education classes and recesses were probabilistically evaluated with a margin of error of $10 \%$ and a confidence interval of $95 \%$. To determine moderate to vigorous physical activity during Physical Education classes and recess, the System for Observing Fitness Instruction Time (SOFIT) was utilized as a measurement instrument (Mckenzie et al., 1992). The SOFIT protocol evaluates teachers qualitatively and quantitatively, through four students (two men and two women) that represent the class. In total, 232 students enrolled in educational centers with an average age of $9.6 \pm 2.9$ years were evaluated (boys $n=116$ and girls $n$ = 116). The length of each Physical Education class was of 50 minutes. Each student was observed in a rotating sequence of twelve intervals for twenty seconds, repeating the observations throughout the class.

To record the activity, an audio player that indicates the recording time and the subject to be evaluated was utilized as a guide. According to the SOFIT method, five codes that represent the student's physical activity following the teacher's instructions were followed, the evaluator knew and memorized the operational definitions of the codes, which are numbered as follows: 1. Lying down, 2. Sitting, 3. Standing, 4. Walking, and 5. Very active, which corresponds to running, or activity with higher energy expenditure. The moderate to vigorous physical activity performed in class represents the percentage sum of codes 4. Walking and 5. Very active of the total time of the Physical Education class. According to the procedures of the SOFIT instrument, after the Physical Education class, the same students evaluated during Physical Education were assessed during recess, which lasted 30 minutes. 


\subsection{STATISTICAL ANALYSIS}

For the statistical analysis, the Statistical Package for the Social Sciences (SPSS version 23) was utilized, determining the descriptive statistics and the percentage difference $(\Delta \%)$ of physical activity of deaf and hearing-impaired students during the Physical Education class, and recess. As a cross-sectional study, when comparing fixed variables, these were divided into two groups, students with deafness and hearing impairment, having physical activity in Physical Education classes, and recess as random variables to calculate the equality of the variance. Parametric statistics were utilized through the Student's t-test for independent samples, determining a level of $\alpha \leq .05$, that is, $5 \%$ as a percentage of error of the statistical test.

\section{RESULTS AND DISCUSSION}

The research evaluated 58 Physical Education classes and recess of the first to sixth grades of primary school, with an average duration in minutes of $45.9 \pm 7.1$ and $30.7 \pm 2.3$ respectively. Table 1 presents the descriptive statistics of physical activity of the five codes evaluated by SOFIT: 1. Lying Down, 2. Sitting, 3. Standing, 4. Walking, and 5. Very Active.

\section{Table 1}

Descriptive statistics of physical activity during Physical Education and school recess among hearing-impaired students

\begin{tabular}{l|c|c|c|c|c|c|c|c}
\hline \multirow{2}{*}{\multicolumn{1}{c|}{ Physical Activity }} & \multicolumn{4}{|c|}{ Physical Education } & \multicolumn{4}{c}{ School Recess } \\
\cline { 2 - 9 } & $\mathbf{M}$ & & SD & Rank & M & & SD & Rank \\
\hline 1) Lying Down (min) & 1.3 & \pm & .4 & $0-2.1$ & 1 & \pm & .3 & $0-2.5$ \\
2) Sitting (min) & 5.9 & \pm & 1.2 & $0-6.3$ & 9 & \pm & 2.8 & $0-1233$ \\
3) Standing (min) & 23.9 & \pm & 6.2 & $9.3-29.7$ & 7.9 & \pm & 2.5 & $2.6-10.3$ \\
4) Walking (min) & 10.3 & \pm & 2.1 & $3-10.6$ & 7.2 & \pm & 2.4 & $2-7.1$ \\
5) Very Active (min) & 4.5 & \pm & .3 & $2-7$ & 4.9 & \pm & 2 & $1.1-6.4$ \\
\hline
\end{tabular}

The normality of the groups and the homogeneity of variance of the data were verified through the Kolmogorov-Smirnov test with a degree of significance of P-Value $\geq .05$. The student's t-test reported significant differences in moderate to vigorous physical activity in Physical Education with a percentage difference of $25.2(\Delta \%)$ with respect to school recess (.001). The calculation of the equality of variance of moderate to vigorous physical activity can be observed in Figure 1. 


\section{Figure 1}

Moderate to vigorous physical activity during Physical Education and school recess among hearing-impaired students

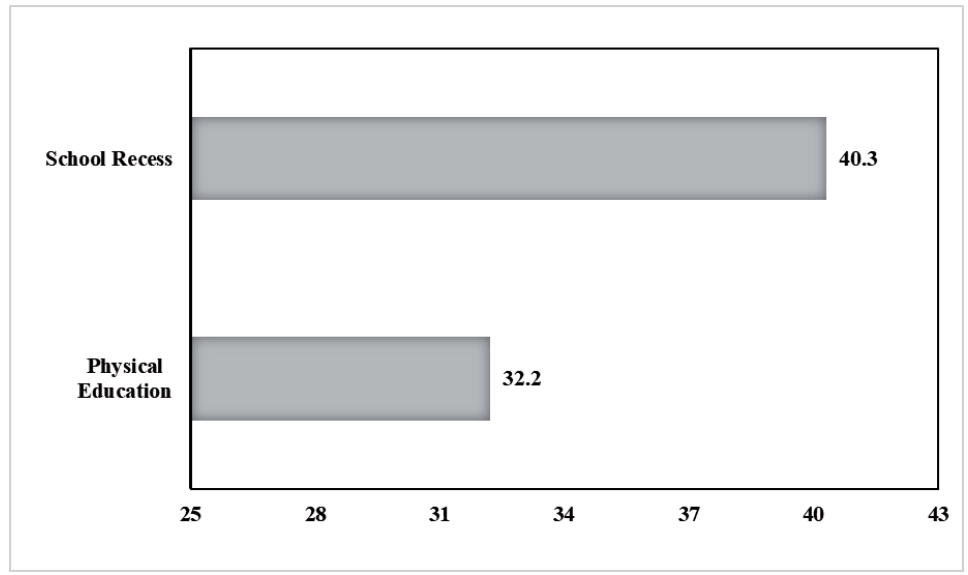

The main result of this research was that the average values of moderate to vigorous physical activity, adding percentage codes 4 and 5, were higher during school recess than in Physical Education classes in students with hearing impairment. When reviewing the state of the art, a study that utilized the same methodological procedure through SOFIT evaluation in educational centers for the disabled also reports a greater moderate to vigorous physical activity in minutes during school recess of 8.9 and in Physical Education of 7.8 (Sit et al., 2007). Within the Mexican context, according to our knowledge, only the results of research in educational institutions with students without diagnosed disabilities are reported, which reported similar patterns of moderate to vigorous physical activity with percentage averages during the recess of 50\% and 41\% in Physical Education in primary education students (Hall-López et al., 2017); and at the secondary level of 50\% during school recess and 37.2\% in Physical Education classes (Hall-López et al., 2018). Regarding the global practice of physical activity, the pattern coincides with studies that refer to less practice in children and youth with disabilities, compared to the population without disabilities (Jung et al., 2018; Li et al., 2019). In our research, the evaluated moderate to vigorous physical activity of students with hearing impairment was $32.2 \%$, which when compared with those internationally established by the National Association of Sport and Physical Education (NASPE) does not achieve moderate to vigorous physical activity for at least $50 \%$ of the class time (Baghurst et al., 2015). Recess is an important space where students can practice physical activity, and it has been shown to contribute to the recommendations for daily physical activity established by the WHO (Ridgers et al., 2011).

To teach schoolchildren with disabilities, Physical Education teachers require adequate training (González \& Macías, 2018; Rubinstein \& Franco, 2020). In the case of teaching Physical Education to deaf and hearing-impaired students, specific methods have been recommended, adapting communication through sign language and strategies that promote motor skill development (Andrade \& Freitas, 2016; Barboza et al., 2019; Fiorini \& Manzini, 
2018). However, when analyzing the results, knowing the multiple benefits of physical activity in terms of quality of life for deaf and hearing-impaired schoolchildren (Kitterick et al., 2015), constructively, strategies are required so that teachers increase the time of moderate to vigorous physical activity during Physical Education class, focusing on tasks that promote coordination (Dantas \& Manoel, 2009), that in the case of people with hearing impairment, would favor the motor skill learning difficulties associated to rhythm, synchronization, adaptation, location in space-time, laterality, orientation and reaction speed (Jafarnezhadgero et al., 2017; Rajendran \& Roy, 2011; Walicka-Cupryś et al., 2014).

\section{Conclusions}

The state of the question, identifies few studies that evaluate physical activity during Physical Education classes and recess in students with hearing impairment, assessed with SOFIT instrument, the study found statistically significant differences, with greater physical activity performed during recess than in Physical Education class, this same pattern can be found in studies performed in educational contexts with students without disability. Based on the results in Physical Education, it is recommended for teachers, aim content towards the development of skills, emphasizing participation in physical coordination capacities where moderate to vigorous physical activity is increased with higher values, than those presented during recess. In the future, it would be important to perform a greater number of studies evaluating variables that favor participation in physical activity in this population, to provide more information about the teaching-learning process provided by Physical Education professionals who work around students with hearing impairment.

\section{REFERÊNCIAS}

Andrade, J., \& Freitas, A. (2016). Possibilidades de atuação do professor de educação física no processo de aprendizagem de alunos com deficiência. Movimento, 22(4), 1163-1176. doi:https://doi. org/10.22456/1982-8918.64231

Baghurst, T., Langley, J., \& Bishop, J. (2015). Physical educators' perceptions of their use of NASPE standards. The Physical Educator, 72(5), 324-341. https://doi.org/10.18666/TPE-2015V72-I5-6194

Baquet, G., Aucouturier, J., Gamelin, F. X., \& Berthoin, S. (2018). Longitudinal follow-up of physical activity during school recess: impact of playground markings. Frontiers in public health, 6, 283. https://doi.org/10.3389/fpubh.2018.00283

Barboza, C., Ramos, A., Abreu, P., \& Castro H. (2019). Physical Education: adaptations and benefits for deaf students. Creative Education, 10, 714-725. doi: 10.4236/ce.2019.104053

Chen, W., Hammond-Bennett, A., Hypnar, A., \& Mason, S. (2018). Health-related physical fitness and physical activity in elementary school students. BMC public health, 18(1), 195. https://doi. org/10.1186/s12889-018-5107-4

Dantas, L., \& Manoel, E. (2009). Crianças com dificuldades motoras: questôes para a conceituação do Transtorno do Desenvolvimento da Coordenação. Movimento, 15(3), 293-313. doi:https://doi. org/10.22456/1982-8918.3908 
Fiorini, M. L. S., \& Manzini, E. J. (2018). Strategies of Physical Education teachers to promote the participation of students with hearing impairment in classrooms. Revista Brasileira de Educação Especial, 24(2), 183-198. https://doi.org/10.1590/s1413-65382418000200003

Franco, E. S., \& Panhoca, I. (2008). Vestibular function in children underperforming at school. Brazilian Journal of Otorhinolaryngology, 74(6), 815-825. http://www.bjorl.org/en-vestibularfunction-in-children-underperforming-articulo-S1808869415301415

Galbraith, L., \& Normand, M. (2017). Step it up! Using the good behavior game to increase physical activity with elementary school students at recess. Journal of Applied Behavior Analysis, 50(4), 856860. https://doi.org/10.1002/jaba.402

González, I., \& Macías, D. (2018). La formación permanente como herramienta para mejorar la intervención del maestro de educación física con alumnado con discapacidad. Retos, 33, 118-122. https://recyt.fecyt.es/index.php/retos/article/view/55056

Hall-López, J. A., Ochoa-Martínez, P. Y., Zuñiga, R., Monreal, L. R., \& Sáenz-López, P. (2017). Moderate-to-vigorous physical activity during recess and physical education among mexican elementary school students. Retos, 31, 137-139. https://recyt.fecyt.es/index.php/retos/article/ view/49640

Hall-López, J. A., Ochoa-Martínez, P. J., Macías, R. A., Zuñiga, R., \& Sáenz-López, P. (2018). Actividad física moderada a vigorosa en educación física y recreo en estudiantes de primaria y secundaria de la frontera México-USA. Sportis: Revista Técnico-Cientifica del Deporte Escolar, Educación Física y Psicomotricidad, 4(3), 426-442. https://doi.org/10.17979/sportis.2018.4.3.3175

Hollis, J. L., Williams, A. J., Sutherland, R., Campbell, E., Nathan, N., Wolfenden, L., Morgan, P. J., Lubans, D. R., \& Wiggers, J. (2016). A systematic review and meta-analysis of moderateto-vigorous physical activity levels in elementary school physical education lessons. Preventive Medicine, 86, 34-54. https://doi.org/10.1016/j.ypmed.2015.11.018

Jafarnezhadgero, A. A., Majlesi, M., \& Azadian, E. (2017). Gait ground reaction force characteristics in deaf and hearing children. Gait \& posture, 53, 236-240. https://doi.org/10.1016/j. gaitpost.2017.02.006

Jung, J., Leung, W., Schram, B. M., \& Yun, J. (2018). Meta-Analysis of Physical Activity Levels in Youth With and Without Disabilities. Adapted physical activity quarterly: APAQ, 35(4), 381-402. https:// doi.org/10.1123/apaq.2017-0123

Jung, L., Marques, A., Kalinoski, A., \& Xavier, G. (2013). Cotidiano da prática de atividade física de crianças e jovens com deficiências da rede municipal de pelotas- RS. Movimento, 19(2), 207-226. https://doi.org/10.22456/1982-8918.30181

Kitterick, P. T., Lucas, L., \& Smith, S. N. (2015). Improving health-related quality of life in singlesided deafness: a systematic review and meta-analysis. Audiology and Neurotology, 20(1), 79-86. doi: $10.1159 / 000380753$

Li, C., Haegele, J., Haegele, \& Wu, L. (2019). Comparing physical activity and sedentary behavior levels between deaf and hearing adolescents. Disability and Health Journal, 12(3), 514-518. doi: 10.1016/j.dhjo.2018.12.002

Li, R., Sit, C. H. P., Yu, J. J., Duan, J., Fan, J., Mckenzie, T., \& Wong, S. (2016). Correlates of physical activity in children and adolescents with physical disabilities: A systematic review. Preventive Medicine, 89, 184-193, doi: 10.1016/j.ypmed.2016.05.029

Mckenzie, T. L., Sallis, J. F., \& Nader, P. R. (1992). Sofit-System for Observing Fitness Instruction Time. Journal of Teaching in Physical Education, 11(2), 195-205. https://doi.org/10.1123/jtpe.11.2.195 
McLennan, N., \& Thompson, J. (2015). Educación física de calidad (EFC): guía para los responsables políticos. Organización de las Naciones Unidas para la Educación, la Ciencia y la Cultura UNESCO. http://www.unesco.org/new/es/social-and-human-sciences/themes/physical-education-and-sport/ policy-project/

Ochoa-Martínez, P. Y., Hall-López, J. A., Carmona, A., Morales, M., Alarcón, E., \& Sáenz-Lopez, P. (2019). Effect of an adapted program of Physical Education in children with hearing disability on motor coordination. MHSalud: Revista En Ciencias Del Movimiento Humano Y Salud, 16(2), 1-11. https://doi.org/10.15359/mhs.16-2.2

Ochoa-Martínez, P. Y., Hall-López, J. A., Carmona, A., Reyes, Z., Sáenz-López, P., \& Conde, C. (2018). Análisis comparativo de un programa educación física en niños con discapacidad auditiva sobre la edad motora equivalente. Retos, 35, 310-313. https://recyt.fecyt.es/index.php/retos/article/view/67190

Rajendran, V., \& Roy, F. G. (2011). An overview of motor skill performance and balance in hearing impaired children. Journal of the Italian Society of Pediatrics, 37(33), 1-5. doi: 10.1186/1824-7288-37-33

Ridgers, N., Carter, L., Stratton, G., \& Mckenzie, T. (2011). Examining children's physical activity and play behaviors during school playtime over time. Health Education Research, 26(4), 586-595. https://doi.org/10.1093/her/cyr014

Rubinstein, S., \& Franco, V. (2020). El campo de la discapacidad desde la perspectiva de los docentes que cursan la especialización en actividad física adaptada y discapacidad Del IUACJ. Revista Brasileira de Educação Especial, 26(1), 17-34. https://doi.org/10.1590/s1413-65382620000100002

Rupali, G. (2005). Research involving children: regulations, review boards and reform. Journal of Health Care Law and Policy, 8(2), 264-330. https://digitalcommons.law.umaryland.edu/jhclp/vol8/iss2/6

Simōes, A., Lorenzini, A., Gavioli, R., Caminha, I., Souza Júnior, M., \& de Melo, M. (2018). A Educação Física e o trabalho educativo inclusivo. Movimento, 24(1), 35-48. doi:https://doi. org/10.22456/1982-8918.73009

Sit, C. H., McManus, A., McKenzie, T. L., \& Lian, J. (2007). Physical activity levels of children in special schools. Preventive medicine, 45(6), 424-431. https://doi.org/10.1016/j.ypmed.2007.02.003

Sit, C., Huang, W. Y., Yu, J. J., \& McKenzie, T. L. (2019). Accelerometer-assessed physical activity and sedentary time at school for children with disabilities: seasonal variation. International Journal of Environmental Research and Public Health, 16(17), 3163. https://doi.org/10.3390/ijerph16173163

Thomas, J. R., Nelson, J. K., \& Silverman, S. J. (2015). Research Methods in Physical Activity (7th. ed.). Human Kinetics. http://www.humankinetics.com/products/all-products/research-methodsin-physical-activity-7th-edition

Walicka-Cupryś, K., Przygoda, Ł., Czenczek, E., Truszczyńska, A., Drzał-Grabiec, J., Zbigniew, T., \& Tarnowski, A. (2014). Balance assessment in hearing-impaired children. Research In Developmental Disabilities, 35(11), 2728-34. doi: 10.1016/j.ridd.2014.07.008

World Health Organization. (2010). Global recommendations on physical activity for health. https://www. who.int/dietphysicalactivity/factsheet_recommendations/en/

World Health Organization. (2011). World report on disability. https://www.who.int/publicationsdetail/world-report-on-disability

World Health Organization. (2013). International Classification of Functioning, Disability and Health (ICF). http://www.who.int/classifications/icf/en-

Recebido em: 13/06/2020

Reformulado em: 03/09/2021

Aprovado em: 05/09/2021 